\title{
Inovasi Pembelajaran Dengan Metode Belajar Bersama Alam (BBA) Guna Membangun Karakter Anak Semenjak Dini Pada Sekolah Alam Muara Bungo (Samo)
}

\author{
Laili Rahmi ${ }^{1}$, Rina Juliana ${ }^{2}$, Dedi Yuisman ${ }^{3}$, Mualimin ${ }^{4}$, Ulfa Adilla ${ }^{5}$ \\ Institut Agama Islam (IAI) Yasni Bungo ${ }^{1}$, Universitas Islam Negeri Sultan Thaha \\ Saifuddin $\mathrm{Jambi}^{2}$, Institut Agama Islam (IAI) Yasni Bungo ${ }^{3}$, Institut Agama Islam \\ (IAI) Yasni Bungo ${ }^{4}$ \\ adillahasan@gmail.com¹, rinajuliana@uinjambi.ac.id², dediyuisman@gmail.com³ \\ limminhoo814@gmail.com ${ }^{4}$
}

\begin{abstract}
Abstrak
Observasi awal yang peneliti lakukan pada sekolah alam muara bungo ini meninggalkan kesan yang sangat menarik. Lingkungan sekolah yang indah dan asri menyatu dalam keramahan, ketertiban dan kecerdasan anak-anaknya. Hal ini tentunya memberi kenyamanan bahkan rasa takjub bagi siapapun yang mengunjungi. Berbagai jenis tanaman menghiasi halaman, pagar, ruangan dan juga sebuah green lab yang mengoleksi berbagai jenis bunga dan tanaman buah-buahan yang dapat menjadi "hadiah" atau oleh-oleh bagi setiap tamu yang datang. Semua tanaman ini tumbuh dengan indahnya tanpa terlihat rusak atau patah meski berada diantara permainan anak-anak. Hal yang akan menjadi tanda tanya bagaimana anak-anak yang masih berada diusia dini ini telah dapat mengerti untuk menjaga dan menghargai lingkungannya.

Peneliti memperhatikan juga bagaimana hubungan sosial anak-anak ini terjalin dengan baik termasuk terhadap anak yang berkebutuhan khusus (ADHD). Guru

\footnotetext{
${ }^{1}$ Prodi Pendidikan Guru Madrasah Ibtidayah, Institut Agama Islam (IAI) Yasni
} Bungo, Jln. Lintas Sumatera KM. 4 Sungai Binjai Kec. Bathin III Kab. Bungo Jambi 37211. Jambi.

${ }^{2}$ Prodi Pendidikan Agama Islam, Universitas Islam Negeri Sultan Thaha Saifuddin

${ }^{3}$ Prodi Pendidikan Guru Madrasah Ibtidayah, Institut Agama Islam (IAI) Yasni Bungo, Jln. Lintas Sumatera KM. 4 Sungai Binjai Kec. Bathin III Kab. Bungo Jambi 37211.

${ }^{4}$ Prodi Pendidikan Islam Anak Usia Dini, Institut Agama Islam (IAI) Yasni Bungo, Jln. Lintas Sumatera KM. 4 Sungai Binjai Kec. Bathin III Kab. Bungo Jambi 37211.
\end{abstract}


mendampingi agar tidak terjadinya keributan dan mereka dapat merasa nyaman antara satu sama lainnya. Peneliti juga merasakan keramahan anak-anak ini dan merasa takjub ketika mereka menunjukkan kefasihannya dalam melafalkan hadits-hadits nabi yang menjadi pedoman bagi mereka dalam bersikap atau berperilaku sehari-hari. Berdasarkan hal ini dapatlah diketahui bahwa karakter anak-anak di sekolah alam muara bungo telah terbina dengan baik, tidak hanya pada sikap menjaga lingkungan namun juga menghargai sesama serta meneladani kemuliaan akhlak Rasulullah SAW dengan pemaknaan terhadap hadits-haditsnya.

Berdasarkan pemaparan di atas maka akan dilakukan penelitian mengenai "Inovasi Pembelajaran dengan Metode Belajar Bersama Alam (BBA) Guna Membangun Karakter Anak Semenjak Dini pada Sekolah Alam Muara Bungo (SAMO)"

\section{Keyword: Inovasi Pembelajaran, Metode BBA, Membamgun Karakter, Sekolah Alam Muara Bungo}

\section{A. Pendahuluan}

Pemerintah Indonesia dalam rangka pembentukan karakater masyarakat, mengintegrasikan karakter dalam pendidikan dengan memasukkan nilai-nilai karakter pada tiap pembelajaran yang dilakukan di sekolah. Pendidikan karakter merupakan kebijakan pemerintah yang ditetapkan dalam Undang-Undang Republik Indonesia Nomor 20 Tahun 2003 Pasal 3 tentang Sistem Pendidikan Nasional yaitu "Pendidikan nasional berfungsi mengembangkan kemampuan dan membentuk watak serta peradaban bangsa yang bermartabat dalam rangka mencerdaskan kehidupan bangsa, bertujuan untuk berkembangnya potensi peserta didik agar menjadi manusia yang beriman dan bertakwa kepada Tuhan Yang Maha Esa, berakhlak mulia, sehat, berilmu, cakap, kreatif, mandiri, dan menjadi warga negara yang demokratis serta bertanggung jawab".

Sekolah alam sejak diperkenalkan oleh Lendo Novo pada tahun 1998 terus mengalami perkembangan hingga tersebar semakin banyak diberbagai wilayah dan tergabung dalam Jaringan Sekolam Alam Nusantara (JSAN). Selaku founder, konsep yang diusungnya adalah menghadirkan lembaga pendidikan dengan kualitas terbaik namun dengan biaya relatif terjangkau oleh masyarakat. Pada umumnya sekolah yang dikenal dengan kualitas terbaik juga berbiaya cukup besar yang pada akhirnya hanya mampu diikuti oleh kalangan tertentu. Pada dasarnya hal ini cendrung dipengaruhi oleh ketersediaan infrastruktur sedangkan mutu utama pendidikan sebenarnya dipengaruhi oleh guru serta sistem atau kurikulum pembelajaran yang dinamis serta inovatif. 
Melalui Studium Generale KU 4078 pada Institut Teknologi Bandung (ITB), Lendo Novo menyinggung keberhasilan pendidikan Finlandia yang telah menjadi sorotan dunia bahwa sistem pembelajarannya tidak berfokus pada apa yang harus dicapai siswa secara teoretis dan keberhasilan yang diukur secara numerik, namun para siswa belajar dengan tanpa beban mengutamakan kebahagiaan bagi mereka hingga akhirnya menununjukkan prestasi terbaik. Berbagai laboratorium tersedia sesuai bakat dan minat siswa serta pendampingan dari tenaga pendidik yang berkompeten. Hal ini yang mulai disadur dalam kurikulum nasional berupa kurikulum 2013 (K-13) dengan integrasi pembelajaran yang menyeluruh sehingga dapat meliputi berbagai karakteristik dan kemampuan siswa. Keberhasilan pendidikan Finlandia dapat menjadi tolak ukur bahwa Indonesia juga mungkin untuk mencapainya dengan memaksimalkan potensi sumber daya alam (SDA) serta sumber daya manusia (SDM) termasuk kerja sama antara tenaga pendidik serta orang tua atau masyarakat.

Kondisi geografis Indonesia serta keragaman hayati yang tinggi menjadi sumber dan media pembelajaran yang dapat dieksplorasi untuk pembelajaran yang lebih baik bagi siswa atau anak. Konsep pendidikan dengan basis menciptakan interaksi siswa atau anak terhadap alam memberikan kesan dan pengalaman yang lebih berarti. Suhendi dan Murdiani (2012) menyebutnya dengan Belajar Bersama Alam (BBA).

Yudhistira (2013:1) menegaskan bahwa pemanfaatan alam oleh manusia dalam dunia pendidikan memiliki kesan baru dalam proses belajar mengajar sebagai upaya yang dilakukan dalam inovasi pendidikan untuk mencapai tujuan pembelajaran yang optimal. Oleh karena itulah, sekolah alam dapat dijadikan contoh sebagai sekolah yang membentuk peserta didiknya untuk memiliki karakter dan akhlak mulia serta memiliki kecintaan terhadap lingkungan sekitar.

Karakter dapat dibentuk melalui pendidikan, karena pendidikan merupakan alat yang paling efektif untuk menyadarkan individu dalam jati diri kemanusiaannya. Dengan pendidikan akan dihasilkan manusia yang berkarakter dalam artian memiliki perilaku yang terpuji. Dalam berbangsa dan bernegara karakter merupakan hal yang sangat esensial, hilangnya karakter maka hilanglah generasi penerus bangsa. Oleh karena itu, karakter harus dibentuk agar menjadi bangsa yang bermartabat.

Sebuah survey yang dilakukan oleh Dr. Gloria Julius dari Primrose Schools pada tahun 2016 menemukan bahwa 92\% orang tua mengakui pentingnya pembentukan karakter anak yang kuat dan positif sejak dini mengingat mereka berada pada masa atau era digital. Dari survey yang sama juga ditemukan bahwa hampir 50\% dari orang tua mengaku bahwa mereka belum paham bagaimana dan kapan sebaiknya 
pembentukan karakter ini bisa dimulai. Para pendidik dan akademisi pun semakin gencar menyatakan pentingnya pembentukan karakter semenjak dini yang dilakukan mulai dari rumah (keluarga) hingga sekolah. Berbagai hasil penelitian juga menegaskan bahwa karakter positif dan kuat yang dimiliki oleh seorang anak akan meningkatkan performa mereka di sekolah, mendapatkan nilai yang lebih baik serta memiliki hubungan sosial yang juga lebih positif.

Salah satu sekolah alam yang ada dikenal dengan Sekolah Alam Muara Bungo (SAMO) yang terletak di kabupaten Bungo Provinsi Jambi. Sosok yang paling berperan dalam mendirikan lembaga ini adalah Nining Wilasari yang juga merupakan istri dari wakil Bupati yang sedang dalam masa jabatan. Sebagaimana konsep utama dari sekolah alam yaitu menggunakan alam sebagai media utama bagi pembelajaran anak didiknya, SAMO memiliki target strategis menciptakan anak didiknya menjadi khalifah dimuka bumi dengan mengelola alam yang menjadi investasi sumber daya manusia untuk masa depan. Kurikulum yang diterapkan merupakan perpaduan kurikulum Diknas dengan Akademi Kurikulum Sekolah Alam (Akar Alam) dan tetap menggunakan peraturan menteri nomor 146 dan 137 tahun 2014.

Observasi awal yang peneliti lakukan pada sekolah alam muara bungo ini meninggalkan kesan yang sangat menarik. Lingkungan sekolah yang indah dan asri menyatu dalam keramahan, ketertiban dan kecerdasan anak-anaknya. Hal ini tentunya memberi kenyamanan bahkan rasa takjub bagi siapapun yang mengunjungi. Berbagai jenis tanaman menghiasi halaman, pagar, ruangan dan juga sebuah green lab yang mengoleksi berbagai jenis bunga dan tanaman buah-buahan yang dapat menjadi "hadiah" atau oleh-oleh bagi setiap tamu yang datang. Semua tanaman ini tumbuh dengan indahnya tanpa terlihat rusak atau patah meski berada diantara permainan anak-anak. Hal yang akan menjadi tanda tanya bagaimana anak-anak yang masih berada diusia dini ini telah dapat mengerti untuk menjaga dan menghargai lingkungannya.

Peneliti memperhatikan juga bagaimana hubungan sosial anak-anak ini terjalin dengan baik termasuk terhadap anak yang berkebutuhan khusus (ADHD). Guru mendampingi agar tidak terjadinya keributan dan mereka dapat merasa nyaman antara satu sama lainnya. Peneliti juga merasakan keramahan anak-anak ini dan merasa takjub ketika mereka menunjukkan kefasihannya dalam melafalkan hadits-hadits nabi yang menjadi pedoman bagi mereka dalam bersikap atau berperilaku sehari-hari. Berdasarkan hal ini dapatlah diketahui bahwa karakter anak-anak di sekolah alam muara bungo telah terbina dengan baik, tidak hanya pada sikap menjaga lingkungan namun juga menghargai sesama serta meneladani kemuliaan akhlak Rasulullah SAW dengan pemaknaan terhadap hadits-haditsnya. 
Berdasarkan pemaparan di atas maka akan dilakukan penelitian mengenai "Inovasi Pembelajaran dengan Metode Belajar Bersama Alam (BBA) Guna Membangun Karakter Anak Semenjak Dini pada Sekolah Alam Muara Bungo (SAMO)”

\section{B. Pembahasan}

\section{Kajian Teori}

\section{a. Metode Belajar Bersama Alam (BBA)}

Alam pada kata sekolah alam mempunyai dua makna: pertama, Alam; dalam artian pengalaman, kedua Alam; semesta alam, makhluk, dan segala sesuatu yang diciptakan ALLAH SWT, baik alam sebagai makhluk dan alam sebagai ilmu dan pengalaman berasal dari akar kata yang sama. Sekolah alam percaya bahwa alam dan pengalaman adalah guru yang terbaik (Suhendi dan Murdiani, 2011:21)

Ciri-ciri dari metode ini diuraikan oleh Riadi sebagai berikut:

1) Belajar menggunakan potensi Sumber Daya Alam (SDA)

SDA dijadikan sebagai laboratorium alam (greenlab), khususnya SDA yang ada di sekolah dan di daerah sekitarnya. Sekolah mempelajari dan mengangkat potensi lokal yang ada, berdasarkan karakteristik lingkungannya. Oleh karena itu BBA bersifat insitu development atau khas bila dibanding daerah lain. Kegiatan pembelajaran sekolah yang berlatar lingkungan hutan/gunung akan berbeda dengan lingkungan pantai. Dalam titik tertentu, sekolah akan memainkan peran konservasi atau penyelamatan keanekaragaman hayati. Termasuk didalamnya kegiatan pengelolaan 3R sampah: Reduce, re-use, recycle.

2) Menghargai culture atau kearifan lokal (lokal wisdom)

Warga sekolah bergerak bersama-sama dalam menjaga dan melestarikan kekayaan ragam budaya, khususnya kearifan lokal (nilai-nilai positif). Sekolah dapat mengadakan semacam tema Indonesian Culture dan dipungkasi performance akbar sebagai puncak tema dengan melibatkan masyarakat atau pihak luar. Selama pembelajaran itu, guru dapat mengelaborasi kebudayaan suatu daerah seperti cara hidup, bahasa, makanan, pakaian, rumah tinggal, kesenian, ketokohan/pahlawan dan nilai-nilai kearifan yang menjadi ciri khas daerah itu.

3) Belajar dengan eksplorasi

Metode ini sering dipakai saat siswa melakukan observasi atau pengamatan terhadap suatu hal atau kejadian. Dapat pula dikorelasikan dengan 
kompetensi dasar atau berdasarkan masalah riil yang sedang dihadapi sekolah atau daerah sekitar sekolah. Misalnya, eksplorasi terhadap penyebab banjir. Eksplorasi ini akan semakin baik jika sampai pada kesimpulan dan alternatif solusi.

\section{4) Belajar dengan eksperimen}

Metode ini digunakan saat hendak membuktikan sesuatu atau menghilangkan rasa penasaran. Ciri-cirinya, ada tahapan yang jelas, dari identifikasi masalah, pembangunan hipotesis dan pembuktian lewat perlakuan hingga keluar konklusi. Eksperimen ini dapat terkait SDA ataupun eksperimen kreatif. Contoh eksperimen kreatif membuat mobil-mobilan bertenaga angin.

5) Melakukan outing atau fieldtrip

Hal ini dimaksudkan dengan belajar langsung dari ahlinya dengan cara mengunjunginya. Masih terkait dengan tema yang sedang dipelajari. Tujuan outing dapat berupa kunjungan ke personal yang memiliki keahlian tertentu, dapat pula ke institut seperti markas pemadam kebakaran atau ke sebuah komunitas pemukiman, seperti kampung batik.

Pembelajaran di sekolah alam banyak dilaksanakan diruang terbuka, dengan memanfaatkan potensi yang ada dilingkungan sekolah. Hal ini sesuai dengan metode belajar bersama alam. Pada prinsipnya, sekolah alam menggunakan model patut dalam memilih model pembelajaran. Artinya metode apapun yang sesuai dapat digunakan sehingga di sekolah alam yang berbeda kita dapat menemukan model pembelajaran yang berbeda pula (Anonimus).

\section{b. Karakter}

Dalam Kamus Poerwadarminta (Kemendiknas, 2010: 44), karakter diartikan sebagai tabiat; watak; sifat-sifat kejiwaan, akhlak atau budi pekerti yang membedakan seseorang daripada yang lain. Dengan pengertian di atas dapat dikatakan bahwa membangun karakter (character building) adalah proses mengukir atau memahat jiwa sedemikian rupa, sehingga 'berbentuk' unik, menarik, dan berbeda atau dapat dibedakan dengan orang lain.

Menurut Saptono (2011:23) pendidikan karakter merupakan proses transformasi nilai-nilai kehidupan untuk ditumbuh kembangkan dalam kepribadian seseorang sehingga menjadi satu dalam perilaku kehidupan orang itu. Pada hakikatnya, setiap individu memiliki keanekaragaman karakter yang berbeda. Hal ini dipengaruhi oleh berbagai hal seperti keluarga, lingkungan sekitar, kondisi masyarakat, budaya, asal daerah, dan lain sebagainya. 
Lickona (2014:22) menjelaskan bahwa karakter merupakan "A reliable inner disposition to response to situations in a morally good way" Ini berarti bahwa karakter merupakan sifat alami seseorang dalam merespon situasi secara bermoral. Kualitas moral seseorang yang tercermin dari segala tingkah lakunya yang mengandung unsur keberanian, ketabahan, kejujuran, dan kesetiaan, atau perilaku dan kebiasaan yang baik.

Menurut Bambang Q Anees (2008:99) mengutip pendapat Russel William mengilustrasikan bahwa karakter adalah ibarat "otot". "Otot-otot" karakter menjadi lembek apabila tidak pernah dilatih, dan akan kuat dan kokoh kalau sering dilatih. Seperti orang binaragawan (body builder) yang terus menerus berlatih untuk membentuk otot-ototnya. "Otot-otot" karakter akan terbentuk dengan praktik-praktik latihan yang akhirnya akan menjadi kebiasaan. Pendapat tersebut sangat jelas menyatakan bahwa karakter individu akan terbentuk melalui latihan-latihan dan pembiasaan. Penanaman pendidikan karakter tidak bisa hanya sekadar mentransfer ilmu pengetahuan saja, akan tetapi perlu proses, contoh teladan, dan pembiasaan dalam lingkungan dalam peserta didik baik dalam lingkungan keluarga, lingkungan sekolah, maupun lingkungan masyarakat.

Dapat disimpulkan bahwa karakter identik dengan akhlak, sehingga karakter merupakan nilai-nilai perilaku manusia yang universal yang meliputi seluruh aktivitas manusia, baik dalam rangka berhubungan dengan Tuhannya, dengan dirinya, dengan sesama manusia, maupun dengan lingkungannya yang terwujud dalam pikiran, sikap, perasaan, perkataan dan perbuatan berdasarkan norma-norma agama, hukum, tata karma, budaya dan adat istiadat.

\section{Metodologi Penelitian}

\section{a. Jenis Penelitian}

Penelitian ini merupakan penelitian kualitatif dengan pendekatan deskriptif. Menurut Lufri (2007:57-58) penelitian kualitatif merupakan penelitian yang menghasilkan data deskriptif berupa kata-kata tertulis atau lisan dari manusia dan perilaku yang dapat diamati. Penelitian mendeskripsikan suatu gejala, fakta, peristiwa atau kejadian yang sedang atau sudah terjadi. Lubis (2011:16) juga menambahkan bahwa deskripsi dilakukan dengan mengeksplorasi (menemukan), mengidentifikasi, dan mendeskripsikan (menjelaskan) keberadaan subjek, objek, dan/atau kejadian yang diteliti saat ini (current status). 
Sudarwan Danim (2002: 51) mengemukakan bahwa jenis penelitian kualitatif deskriptif, yaitu data yang dikumpulkan berbentuk kata-kata, gambar, bukan angka-angka. Data dikumpulkan untuk menjawab rumusan masalah penelitian, dalam hal ini terkait dengan pembentukan karakter melalui penerapan metode Belajar Bersama Alam (BBA).

\section{b. Tempat dan Waktu Penelitian}

Penelitian ini dilaksanakan pada Sekolah Alam Muara Bungo (SAMO) dengan subyek penelitiannya anak-anak pada tahun ajaran baru 2019/2020 yang berada pada tingkat TK A dan TK B. Anak-anak yang berada dalam kisaran usia 4-6 tahun ini disebut sebagai anak-anak golongan usia dini. Penelitian dilakukan diantara bulan September-Oktober-November 2019.

\section{c. Informan Penelitian}

Informan merupakan orang atau subjek yang dapat memberikan informasi terkait hal yang diteliti. Kepala sekolah sebagai pihak utama dan para guru merupakan informan yang selanjutnya akan diwawancarai untuk melengkapi data penelitian. Apabila memungkinkan peneliti juga akan menjadikan orang tua atau wali murid sebagai informan yang dapat memberikan evaluasi terhadap metode pembelajaran di Sekolah Alam Muara Bungo (SAMO) sebagai lembaga pendidikan anak-anak mereka.

\section{d. Teknik Pengumpulan Data}

Prosedur pengumpulan data adalah cara-cara yang dapat digunakan oleh peneliti untuk memperoleh berbagai jenis data di lapangan, dalam hal ini mengenai metode Belajar Bersama Alam (BBA) di Sekolah Alam Muara Bungo (SAMO). Teknik pengumpulan data yang dilakukan adalah wawancara atau interviu, pengamatan dan dokumentasi. Mengenai teknik pengumpulan data pada penelitian ini, dapat dilihat pada gambar berikut ini:

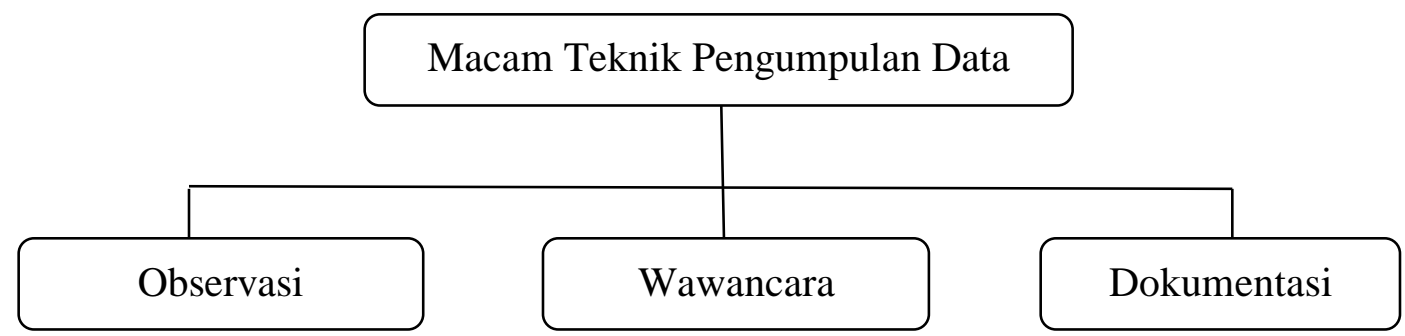


Gambar 3. Macam Teknik Pengumpulan Data

1) Wawancara

Menurut Sugiono (2009: 233) wawancara adalah sebuah dialog yang dilakukan oleh pewawancara (interviewer) untuk memperoleh informasi dari terwawancara (informan). Teknik ini dilakukan dengan cara dialog (face to face atau calling) untuk mengetahui informasi yang mendalam. Dalam hal ini pewancara memakai "wawancara tak terstruktur, yaitu wawancara yang bebas di mana peneliti tidak menggunakan pedoman wawancara yang telah tersusun secara sistematis dan lengkap untuk pengumpulan datanya. Pedoman wawancara yang digunakan hanya berupa garis-garis besar permasalahan yang akan ditanyakan".

2) Observasi

Menurut Amirul Hadi dan Haryono (:94) Observasi ialah pengamatan dan pencatatan yang sistematis terhadap gejala-gejala yang diteliti. Observasi menjadi salah satu teknik pengumpulan data apabila: Pertama, sesuai dengan tujuan penelitian. Kedua, direncanakan dan dicatat secara sistematis. Dan ketiga, dapat dikontrol keandalannya dan kesahihannya". Menurut A. Chaedar Alwasilah (2003: 154) "Teknik ini memungkinkan peneliti menarik kesimpulan ihwal makna dari sudut pandang responden, kejadian, peristiwa, atau proses yang diamati. Lewat observasi ini, peneliti akan melihat sendiri pemahaman yang tidak terucap, bagaimana teori digunakan langsung dan sudut pandang responden yang mungkin tidak tercungkil lewat wawancara atau survai".

\section{3) Pengumpulan Dokumen}

Menurut Sugiono (2009: 240) dokumen adalah catatan peristiwa yang sudah berlalu. Dokumen bisa berbentuk tulisan, gambar, atau karyakarya monumental dari seseorang. Dokumen yang berbentuk tulisan misalnya catatn harian, sejarah kehidupan, ceritera, biografi, peraturan, kebijakan". Pengumpulan dokumen ini digunakan untuk mengetahui dan memeriksa kelengkapan dokumen-dokumen yang telah dikumpulkan dalam penulisan ini, misalnya dokumen yang memuat 
informasi mengenai penerapan Metode Belajar Bersama Alam (BBA) Pada Sekolah Alam Muara Bungo (SAMO).

\section{e. Tekhnik Pemeriksaan Keabsahan Data}

Dalam pemeriksaan atau pengecekkan data ini peneliti menggunakan triangulasi data yang merupakan teknik pemeriksaan keabsahan data yang memanfaatkan sesuatu yang lain di luar daya itu untuk keperluan pengecekan atau sebagai pembanding terhadap data itu. Menurut Lexy. J. Moleong (2000:3). Teknik triangulasi yang paling banyak digunakan ialah pemeriksaan melalui sumber lainnya. Pada penelitian ini penulis membandingkan data yang diperolah dari observasi dan dokumentasi serta hasil wawancara, beberapa pihak diantaranya kepala sekolah, para guru dan orang tua atau wali murid dalam upaya mengetahui dan meningkatkan derajat kepercayaan yang diperoleh. Melalui pengecekaan tersebut dapat diketahui apakah data yang diperoleh penulis memiliki banyak persamaan atau perbedaan dengan sumber data lainnya.

\section{f. Tekhnik Analisis Data}

Menurut Lexy. J. Moleong (2000:29) Analisis data pada penelitian kualitatif adalah upaya yang dilakukan dengan jalan berbagai data, mengorganisasikan data, memilah milah data menjadi satu kesatuan data yang diperolah, mensimtesiskannya, mencari dan menentukan pola, menentukan apa yang diceritakan kepada orang lain. Proses analisis data dimulai dengan menelaah seluruh data yang dikumpulkan dari berbagai sumber yang diperoleh dari kegiatan observasi, wawancara, dokumentasi, kemudian data yang telah terkumpul, dianalisis ditafsirkan dan disimpulkan keadalam bahasa yang mudah dipahami dan logis sesuai dengan penelitian yang dibahas.

Sugiono (2009: 246) mengemukakan bahwa aktivitas dalam analisis data kualitatif dilakukan secara interaktif dan berlangsung secara terus menerus sampai tuntas, sehingga datanya sudah jenuh. Aktivitas dalam analisis data, yaitu data reduction, data display, dan conclusion drawing/verification. Langkah-langkah analisis ditunjukkan pada gambar di bawah ini: 


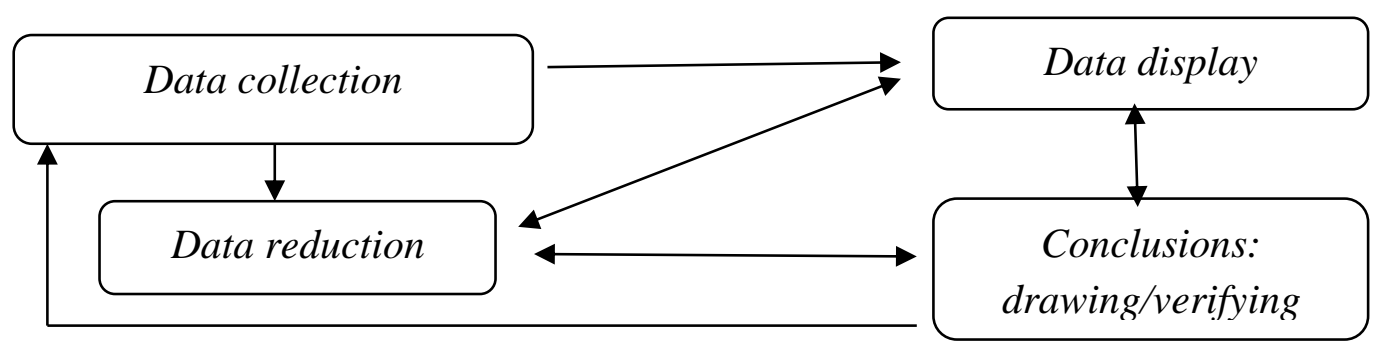

Gambar 3.2 Teknik Analisis Data

1) Pengumpulan Data

Peneliti membuat catatan data yang dikumpulkan melalui observasi, wawancara dan studi dokumentasi yang merupakan catatan lapangan. Semua data merupakan hasil data mentah yang diperoleh peneliti. Semua data tersebut terfokus pada tujuan penelitian yang diinginkan.

2) Reduksi Data

Proses analisis data dimulai dengan menelaah seluruh data yang tersedia dari berbagai sumber, yakni dari pengamatan, wawancara dan dokumentasi. Setelah dipelajari dan dicermati, peneliti memilih data yang penting, membuat kategori dan membuang yang tidak terpakai. Langkah ini merupakan proses penyeleksian, penyederhanaan dan memfokuskan data yang diperoleh peneliti.

3) Penyajian Data

Setelah melalui reduksi data, langkah selanjutnya mendisplaykan data. Penyajiannya dengan uraian singkat, bagan, hubungan antar kategori yang bersifat naratif.

4) Penarikan Kesimpulan

Setelah reduksi data dan penyajian data sudah dilakukan maka langkah terakhir adalah dengan menarik kesimpulan atau verifikasi. Analisis ini menggunakan ketiga komponen yang tersedia yaitu data wawancara, observasi dan dokumentasi.

\section{Pembahasan Hasil Penelitian}

\section{a. Deskripsi Sekolah Alam Muara Bungo (SAMO)}


Sekolah Alam Muara Bungo (SAMO) merupakan lembaga pendidikan yang baru yang diresmikan pada tahun 2018. Pembangunan dilakukan secara bertahap yang dimulai pada 5 Februari 2018. Gagasan pendirian sekolah ini berasal dari Ibu Nining Wilasari selaku ketua GOW kabupaten Bungo dan sekaligus juga sebagai istri wakil bupati dalam masa jabatan 2016-2021. Berdasarkan wawancara oleh metro jambi beliau menyatakan "Ide berdirinya sekolah alam ini berawal dari visi hidup saya untuk memajukan dunia pendidikan di Kabupaten Bungo karena bagi saya orang yang terbaik diantara kita adalah yang paling banyak memberi manfaat bagi orang lain".

Sekolah yang beralamat dijalan Katik Marajo RT.15 RW 05 Kelurahan Cadika, Kecamatan Rimbo Tengah, Kabupaten Bungo ini memiliki visi dan misi sebagai berikut:

Visi: "Mencetak generasi qur'ani yang berakhlak mulia sebagai pemimpin masa depan.

Misi diantaranya:

1) Mengenalkan anak sedini mungkin dengan $\mathrm{Al}$ qur'an dan sunnah melalui kegiatan terstruktur dari sekolah

2) Membentuk sikap dan prilaku anak dengan kegiatan pembiasaan

3) Menanamkan pendidikan, keimanan, ketakwaan dan akhlakul kharimah secara formal

4) Membentuk jiwa kepemimpinan dan enterpreneurship melalui kegiatan yang telah terprogram dari sekolah

5) Pembelajaran dengan metode BBA (Belajar Bersama Alam)

Sekolah alam muara bungo ini memiliki 16 program unggulan yaitu: (1) Tahfidz Qur'an, (2) Baca dan Tulis Al Qur'an, (3) Sholat Dhuha, (4) Iqra'(5) Hafalan hadits, (6) Siroh nabi, (7) Penerapan adab sehari-hari, (8) Cooking, (9) Out Bond, (10) Market Day, (11) Tabungan Bank Sampah, (12) BBA (Belajar Bersama Alam), (13) Outing Class, (14) Family Gathering, (15) One Day With Dady dan Parenting Skill.

Program-program ini diterapkan dengan metode pembelajaran yang berbasis fun learning, action learning dan learning experience.

1) Pilar Sekolah Alam Muara Bungo (SAMO)

Pilar Sekolah Alam Muara Bungo (SAMO) ini dikemas dalam kurikulum yang disebut dengan "akar alam". Kurikulum ini menjadi karakteristik yang membedakan sekolah alam dengan sekolah atau 
lembaga pendidikan lainnya. Realisasi kurikulum ini berdasarkan pada pengembangan bakat dan minat anak serta pembentukan karakter atau habit yang sangat berarti bagi kehidupan mereka dimasa yang akan datang.

2) Pembinaan Akhlak

Pembinaan akhlak dilakukan pada kelas qur'an yang merupakan kelas pagi hari sebelum memulai kegiatan tema pembelajaran. Kegiatannya berupa pembacaan iqra', sholat sunnah dhuha, sirrah nabawiyah dan pengenalan serta penerapan hadits-hadits dalam keseharian. Anak-anak dibimbing dalam membaca iqra' dengan memperhatikan penggunaan makhraj yang tepat. Sholat sunnah dilakukan beberapa kali dalam seminggu secara bergantian antara TK A one) dan TK B. Apabila jadwal TK A yang melaksanakan sholat sunnah dhuha maka TK B akan mendengarkan sirrah nabawiyah, demikian juga sebaliknya.

Anak-anak tidak hanya diajarkan untuk mampu membaca iqra' namun juga pengenalan hadits-hadits terutama yang berkaitan erat dengan kehidupan sehari-hari. Peningkatan pemahaman terhadap hadits ini dilakukan dengan menerapkannya disetiap waktu misalnya ketika seorang anak maupun guru memakan makanan sambil berjalan atau berdiri maka anak-anak maupun guru lain yang melihatnya akan membacakan hadits yang sesuai sebagai tegurannya. Begitu juga terhadap hal-hal lain yang bertentangan dengan sunnah atau ajaran Rasulullah SAW maka setiap guru maupun anak akan berupaya untuk saling mengingatkan.

\section{3) Pengembangan Logika}

Pengembangan logika ini merupakan dasar dari metode BBA (Belajar Bersama Alam). Pembelajaran bersifat kontekstual melalui pengamatan atau penggunaan terhadap objek yang dipelajari secara langsung. Anak-anak juga belajar lebih aktif dengan mereka membangun konsep pengetahuan sendiri dalam pikirannya serta tidak terpusat kepada guru. Pembelajaran seperti ini di samping memberikan pemahaman yang konkrit bagi anak terhadap tema yang dipelajari serta membangun pengalaman belajar juga yang lebih utamanya adalah memberi kebahagiaan bagi anak dalam belajar di sekolah. Mereka tidak akan merasa bahwa belajar sebagai suatu beban atau tekanan bagi dirinya. Adanya kebijakan sekolah dengan tidak memakai pakaian seragam membuat anak-anak semakin riang dalam mengeksplorasi 
alam untuk belajarnya layaknya sedang bermain tanpa merasa ragu atau takut untuk menjadi kotor.

4) Leadership

Leadership merupakan upaya melatih atau membangun jiwa kepemimpinan pada anak-anak melalui berbagai kegiatan yang dilakukan di sekolah maupun di lingkungan luar sekolah. Kegiatan yang paling menarik adalah kegiatan yang mereka sebut dengan "ngebolang" yang mana dalam kegiatan ini anak-anak menjelajahi alam atau berpetualang untuk mengenal lebih dekat lagi mengenai keanekaragaman tumbuhan dan hewan. Pada kegiatan ini anak-anak sekaligus belajar menghargai alam dan melestarikannnya serta mawas diri agar dapat selalu survive ketika berada di alam bebas.

Kegiatan kepemimpinan dengan melatih anak menjadi pribadi yang tangguh dan tidak mudah menyerah seperti ketika mereka berpetualang mereka tidak mudah mengeluh dan merasa capek. Di samping itu kegiatan ini juga dimaksudkan untuk membangun jiwa pemberani dan mandiri pada anak yang sangat perlu bagi mereka tidak hanya dalam kegiatan yang sedang dilakukan namun juga pada kegiatan-kegiatan lainnya di luar sekolah.

5) Pengembangan kewirausahaan

Pengembangan kewirausahaan menjadi program yang diprioritaskan juga di sekolah alam muara bungo sebagai cikal bakal masa depan anak-anaknya. Kegiatan yang menarik dalam pengembangan ini berupa "market day" yang diselenggarakan setiap sebulan sekali. Pada kegiatan ini anak-anak berjualan makanan yang telah disiapkan oleh orang tua mereka dan melalui pendampingan guru, mereka dapat melakukan interaksi jual beli dengan baik. Kegiatan ini sekaligus mengasah kemampuan anak-anak dalam berhitung sehingga menjadi pembelajaran yang kontekstual. Pengalaman yang diperoleh membuat mereka menghargai keberadaan uang dan menyadari adanya tantangan atau kesulitan untuk mendapatkannya sehingga memberikan makna juga bagi mereka untuk berhemat dan menabung.

\section{b. Penerapan Metode Belajar Bersama Alam (BBA)}

\section{1) Sekolah dan Guru sebagai Fasilitator}

Berdasarkan wawancara peneliti dengan kepala sekolah yang biasa dipanggil ustadzah Aliyah, penerapan BBA ini dimulai dari guru serta 
sekolah sebagai tempat belajar anak-anak. Tata kelola tempat atau ruang dirancang sedemikian rupa hingga selaras dengan sebutan sekolah alam. Kelas berupa saung-saung dengan pekarangan yang bersih dan tertata apik hingga tampak indah dan menjadi ruang terbuka belajar yang nyaman.

Guru sebagai cerminan anak-anak dituntut untuk menerapkan sikap menghargai dan memanfaatkan alam dalam aktifitas kesehariannya. Hal sederhana dicontohkan dengan meminimalkan penggunaan plastik sebagai kantong makanan dan menggantinya dengan barang dengan bahan lain yang tidak akan menambah sampah dilingkungan. Menjaga adab, disiplin dan kebersihan menjadi perhatian guru setiap harinya. Guru memberikan keteladanan terhadap anak. Hal sederhana seperti meletakkan suatu barang pada tempatnya, membuang sampah juga pada tempatnya serta duduk setiap akan makan dan minum. Meski dilakukan terhadap hal-hal yang sederhana namun ini diyakini akan membentuk karakter positif bagi anak yang akan berpengaruh terhadap hal-hal urgen lainnya serta masa depan mereka.

Guru juga didorong untuk aktif mencari informasi yang dapat menghasilkan gagasan yang inovatif bagi pembelajaran terhadap anak. Salah satu wujud dari kreatifitas guru ini adalah mengembangkan bahan/modul pembelajaran serta panduan kerja (workseet) yang akan digunakan oleh anak atau siswa.

\section{2) Pembelajaran Tematik}

Bagi anak usia dini orientasi pengembangan dirinya meliputi lima aspek penting yaitu iman dan taqwa, sosial-emosional, bahasa, fisikmotorik dan seni. Aspek ini selalu diupayakan ketercapaiannya melalui pembelajaran yang telah diprogramkan. Kesehariannya anakanak belajar dengan menggunakan modul dan workseet yang telah disiapkan secara mandiri oleh sekolah atau guru.

Setiap konsep selalu dihubungkan dengan dunia nyata dengan anak mengamati dan bertindak secara langsung atau yang disebut dengan belajar secara kontekstual. Sebagai contoh pada tema "daun tumbuhan" maka anak-anak mengumpukan berbagai jenis daun dan mengamati perbedaan bentuknya. Melalui workseet mereka akan memahami adanya bentuk daun yang oval, menjari, pita dan sebagainya. Demikian juga pada tema hewan misalnya "burung", maka dengan objek yang telah disediakan di sekolah mereka 
mengamati secara langsung ciri khususnya, makanan dan perilakunya. Tidak hanya terhadap konsep makhluk hidup namun pada benda mati seperti tema "kendaraan", maka anak-anak tidak hanya mengetahui bentuk kendaraan tersebut namun memahami juga bagaimana aturan berkendara seperti pemakaian helm demi keselamatan berkendara motor dan merawat kendaraan tersebut yang mereka praktekkan dengan langsung mencuci salah satu motor yang ada di sekolah. Melalui pembelajaran secara kontekstual tentunya anak-anak akan memperoleh pengalaman yang bermakna yang sangat penting bagi mereka hingga masa depannya.

Pembelajaran secara kontektsual di atas sama halnya dengan istilah belajar dengan eksplorasi sebagaimana dikemukakan oleh Suhendi dan Murdiani, (2011:21) dimana metode ini sering dipakai saat siswa melakukan observasi atau pengamatan terhadap suatu hal atau kejadian.

\section{3) Greenlab}

Kegiatan utama yang dilakukan dalam greenlab ini adalah "beternak, bercocok tanam dan mengelola sampah". Kegiatan ini dilaksanakan setiap minggunya yaitu pada Rabu pagi. Hal yang unik juga dalam kegiatan ini adalah anak-anak mengenakan pakaian orang tuanya sesuai profesi mereka. Hal ini dimaksudkan agar mereka dapat memahami dan menghargai aktifitas atau pekerjaan yang dijalani orang tuanya setiap hari.

Sebelum melakukan kegiatan anak-anak diperkenalkan dengan alat dan bahan yang diperlukan atau akan digunakan. Hal ini juga termasuk sebagai evaluasi yang ditampilkan pada worksheet untuk menguji pemahaman mereka terhadap kesiapan memulai suatu kegiatan.

Kegiatan greenlab menjadi wahana bagi anak untuk "berani kotor" atau tidak merasa jijik dengan kontak secara langsung terhadap lingkungan. Pada kegiatan bercocok tanam, anak-anak memegang tanah secara langsung dan mengisi polibek hingga menanaminya. Atas rutinitas ini sekolah alam muara bungo memiliki rumah pembudidayaan sendiri yang mengoleksi berbagai jenis bunga dan tanaman buah. Tanaman ini selanjutnya dijadikan hadiah bagi tamu atau pengunjung yang datang. Melalui greenlab bercocok tanam ini anak-anak juga dapat memperhatikan dan mengurusi pertumbuhan tanamannya. Pada jenis sayur-sayuran ketika tiba masa panennya maka dipetik bersama-sama dan dibawa pulang oleh anak-anak untuk 
dimasak oleh ibu mereka di rumah. Dengan hal ini dapat dibayangkan bagaimana sukacita anak-anak maupun orangtua menikmati hasil atas apa yang telah diupayakan di sekolah.

Pada kegiatan beternak anak diajak untuk berinteraksi langsung dengan hewan peliharaan atau ternak yang ada di sekolah. Mereka memberi makan dan merawat hewan tersebut. Melalui kegiatan ini maka guru dapat mengintegrasikan pengetahuan bagi anak untuk mengenal berbagai jenis hewan serta mengamati perilakunya. Kegiatan lainnya dari greenlab yaitu pengelolaan sampah. Anak dibimbing untuk memahami dan mengelompokkan sampah atas sampah organic dan anorganik. Sampah organic selanjutnya diolah juga menjadi pupuk kandang dan dimanfaatkan untuk menyuburkan berbagai tanaman yang ada di sekolah tersebut. Sampah anorganik seperti botol-botol bekas, kardus, kertas dan plastik dikumpulkan pada satu ruang yang menjadi "bank sampah" dengan dibersihkan terlebih dahulu dan ditata secara rapi. Pengelompokkan yang teratur ini menjadi daya tarik dan keindahan ketika kita berkunjung ke sekolah alam ini. Melalui ketersediaan berbagai macam barang dan telah dibersihkan, guru dan anak-anak juga seringkali menggunakan dan membuat media belajar yang menarik. Bank sampah ini selanjutnya dikelola dengan manajemen yang sangat baik hingga menjadi tabungan bagi anak yang mereka terima sebagai uang pada akhir semester atau akhir tahun ajaran baru.

Begitu banyak nilai-nilai positif yang terintegrasi dalam kegiatan greenlab ini. Mulai dari sikap memahami dan menghargai usaha atau jerih payah orang tua dengan mengenakan pakaian kerja mereka, membangun keberanian anak untuk melakukan hal yang baik dan bermanfaat, peduli dan bersungguh-sungguh terhadap apa yang dikerjakan hingga dapat menikmati hasil yang baik, kerja sama yang membina kesabaran dan toleransi, peduli terhadap lingkungan atau tumbuhan dan hewan yang ada disekitar hingga kecermatan dalam mengenali barang-barang yang masih dapat dimanfaatkan dan menghasilkan nilai jual atau keuntungan. Melalui keberadaan bank sampah, anak-anak juga belajar hidup hemat dan menabung untuk kepentingan masa depan. Kegiatan greenlab ini juga membina kemandirian anak hingga menjadi pengalaman berwirausaha dari semenjak dini yang sangat berarti bagi masa depan mereka nantinya. 


\section{4) WWP (Work With Parents)}

Belajar bersama alam juga dapat dilakukan bersama orang tua di rumah yang dikenal dengan WWP. Sekolah menyiapkan modul yang digunakan oleh orang tua sebagai panduan dalam berkegiatan bersama anak. Sebagai contoh kegiatan menanam bunga yang ditetapkan pada modul menggunakan media tanah. Pada anak usia paud media tanam memang masih berupa tanah namun pada usia SD media tanamnya telah meningkat berupa air seperti penanaman dengan teknik hidroponik.

Kegiatan wwp ini dapat meningkatkan efektifitas pembelajaran terutama bila keadaan tidak memungkinkan untuk berkegiatan di sekolah. Sebagai contoh ketika terjadi masalah kabut asap di wilayah jambi termasuk Bungo maka pemerintah kabupaten menginstruksikan untuk libur sekolah. Dengan adanya wwp maka anak tidak ketinggalan materi pelajaran dan mereka tetap dapat belajar bahkan memperoleh pengalaman baru yang menarik dengan belajar dan bekerja sama dengan orang tua.

Kegiatan wwp menjadi andil bagi orang tua dalam memajukan program pembelajaran sekolah. Kegiatan yang tidak monoton dimana orang tua diberi kebebasan untuk berkreasi bersama anak berkenaan dengan tema yang ditetapkan sekolah akan mendorong orang tua menunjukkan skill yang sangat berarti sebagai pengalaman bagi anak. Kesempatan ini menjadikan orang tua berperan sebagai guru sekaligus rekan bagi anak dalam mengupayakan hasil kerja yang terbaik. Kerja sama ini akan menciptakan keakraban orang tua dengan anak serta memotivasi anak untuk terus belajar dan berkarya.

\section{c. Karakter yang Terbentuk Melalui Metode BBA}

Berdasarkan penjabaran dari metode belajar bersama alam di atas maka dapat diuraikan berbagai karakter yang terbentuk pada anak sebagai berikut.

\section{1) Beriman}

Pendekatan guru yang memberikan pemahaman kepada anak mengenai keberadaan dan keteraturan alam yang indah dan dapat menjadi media dan sumber belajar telah membangun karakter beriman dalam diri anak yang menuntun perilaku atau perkembangan karakter positif lainnya dalam diri mereka.

\section{2) Peduli alam/lingkungan}


Sekolah ini merupakan sekolah alam yang menekankan pendidikan karakter pada anak sejak usia dini, disini pembelajaran sebagian dilakukan diluar kelas agar siswa lebih peduli dengan alam atau lingkungan. Lingkungan sekolah juga dibentuk manarik dengan membuat saung-saung sebagai tempat belajar, dengan halaman yang cukup luas dengan tanaman-tanaman bunga yang menghiasi lingkungan sekolah, dan juga sekolah ini jauh dari keramaian sehingga menciptakan suasana yang kondusif.

Berkenaan dengan kegiatan pembelajaran yang berinteraksi langsung dengan alam atau lingkungan maka melahirkan sifat peduli dengan menjaga dan melestarikan lingkungan termasuk juga merawat hewan dan tumbuhan. Hal ini yang mempengaruhi keasrian lingkungan sekolah dengan keberadaan berbagai jenis tanaman buah dan bunga serta keberadaan unggas dan kolam ikan yang tidak rusak oleh aktifitas bermain anak-anak.

Dengan adanya pemanfaatan alam atau lingkungan sebagai media, tanpa disadari siswa, mereka melakukan kegiatan-kegiatan yang sebenarnya ditujukan untuk menanamkan karakter pada dirinya, sehingga apa yang diharapkan lebih mudah tersampaikan dan guru juga berharap siswa akan lebih akrab dengan lingkungan sehingga menumbuhkan rasa cinta akan lingkungan sekitarnya.

\section{3) Toleransi}

Belajar bersama alam juga membina toleransi bagi anak baik terhadap guru dan teman-temannya di sekolah maupun keluarga di rumah. Kerja sama yang dilakukan dalam berbagai kegiatan membuat anak belajar untuk saling menghargai dan membantu. Anak-anak bersikap baik antara satu sama lainnya tanpa mempersoalkan keadaan fisik. Demikian juga ketika di rumah mereka bersedia membantu dan memahami keadaan orang tuanya.

\section{4) Disiplin}

Setiap kegiatan baru akan terlaksana dengan efektif melalui disiplin yang dilakukan oleh anak. Seperti halnya mereka mempersiapkan diri dengan baik sebelum memulai kegiatan. Pada greenlab bercocok tanam misalnya anak-anak telah menyadari perlunya mereka mengenakan sepatu bot, sarung tangan dan topi sebelum memulai kegiatan. Di samping itu dengan pengenalan pengelompokkan sampah (organic dan 
anorganik) juga membina kedisiplinan mereka untuk membuang sampah pada tempatnya yang sesuai.

\section{5) Mandiri}

Karakter ini berkenaan dengan cara belajar anak yang berupaya menemukan pengetahuan sendiri dengan mengamati lingkungan secara langsung atau melakukan eksplorasi. Kemandirian ini akan mengembangkan kemampuan pemecahan masalah yang sangat berarti seiring pertambahan usia dan perkembangan jiwanya.

\section{6) Berani}

Kegiatan pembelajaran seperti pada greenlab menuntut setiap anak untuk ikut terlibat melakukannya sehingga menumbuhkan keberanian mereka untuk melakukan berbagai hal yang menjadi pengalaman seru dalam belajar. Keberanian tidak hanya dalam melakukan suatu kegiatan namun mereka juga belajar untuk berani berpendapat atau bertanya sehingga melatih berpikir kritis dari semenjak dini.

\section{7) Tanggung jawab}

Tanggung jawab pada anak terbina dengan mereka mesti mengerjakan dan menyelesaikan setiap kegiatan atau proyek yang diberikan guru. Guru memberikan pemahaman dan motivasi tentang hasil yang akan mereka peroleh apabila dapat mengupayakan usaha yang terbaik.

\section{8) Hidup Hemat}

Adanya pemanfaatan barang bekas hingga memiliki nilai jual membuka kesempatan anak untuk berusaha dan menabung hingga mereka nantinya dapat menerima hasil atas usaha sendiri. Pengalaman berwirausaha semenjak dini ini sekaligus membina karakter hidup hemat pada anak hingga membuka kesempatan mereka menjadi enterpreneurship yang berjaya di masa depan nantinya.

\section{9) Rajin}

Belajar dengan bereksplorasi yang menjadi pembelajaran yang bermakna bagi anak membuat mereka menjadi rajin belajar dan melakukan berbagai kegiatan demi menemukan hal baru. Karakter rajin ini tidak hanya dalam belajar namun juga dalam bentuk kepedulian seperti rajin membantu orang tua terutama pada kegiatan-kegiatan yang 
biasa mereka lakukan di sekolah seperti bercocok tanam, beternak, membersihkan lingkungan dan sebagainya.

\section{0) Leadership}

Kegiatan pembelajaran yang membawa siswa ke luar dari pekarangan sekolah seperti "ngebolang" dalam rangka mengeksplorasi pengetahuan telah membina jiwa kepemimpinan (leadership) pada anak. Mereka dilatih menjadi pribadi yang tangguh atau tidak mudah menyerah, dapat memecahkan masalah hingga membuat keputusan. Menurut Nifa Septiani (2016) karakter kepemimpinan (leadership) diajarkan salah satunya dalam kegiatan outbound yang memberikan sebuah pengalaman langsung kepada anak untuk mengembangkan nilai - nilai adil, amanah, musyawarah, kerjasama, melindungi, mengayomi, rasa percaya diri, dan menjaga keseimbangan alam

\section{d. Kendala Penerapan Metode Belajar Bersama Alam (BBA)}

Pembelajaran bersama alam yang sangat terkait dengan perkembangan karakter memiliki kendala diantaranya:

1) Masih adanya guru/anak yang belum disiplin dalam mengikuti aturan

Pada sekolah alam muara bungo berlaku 5 pembiasaan yang menjadi orientasi pembinaan karakter yaitu (1) meletakkan sepatu dan sandal pada tempatnya, (2) meletakkan barang yang dipinjam atau diambil pada tempatnya, (3) membudidaya antri, (4) membuang sampah pada tempatnya dan (5) tidak makan dan minum sambil berdiri/berjalan. Meski hal di atas merupakan hal yang mudah untuk dilakukan oleh siapapun namun sebagaimana karakter bukanlah sesuatu yang tercipta dengan sederhana atau terwujud secara instan, hingga terkadang masih ada kelalaian atau ketidakdisiplinan yang dilakukan guru maupun anak.

\section{2) Keterbatasan komunikasi guru dan orang tua}

Keterbatasan komunikasi yang dipengaruhi oleh jarak dan waktu antara guru dengan orang tua menjadikan program pembelajaran bagi anak tidak selalu dapat terwujud secara efektif. Hal lain yang lebih mempengaruhi adalah ketidakselarasan motivasi dan usaha antara sekolah dan keluarga dalam pembinaan karakter anak. Sebagai contoh ketika anak berada di sekolah diajarkan untuk berlaku disiplin, mandiri dan bertanggung jawab namun ketika di rumah hal tersebut kurang menjadi perhatian orang tua. Ini tentu saja menyebabkan upaya sekolah 
atau guru menjadi percuma atau perkembangan karakter yang diharapkan menjadi tidak maksimal.

\section{e. Solusi Mengatasi Kendala Penerapan Metode Belajar Bersama Alam}

1) Solusi yang pertama yaitu melalu metode ketaladanan dalam kegiatan sehari-hari kepala sekolah, guru, dan staf admnistrasi dapat menjadi teladan dan model yang baik bagi anak-anak disekolah, tanpa keteladanan maka anak-anak hanya akan menganggap ajakan moral yang disampaikan sebagai sesuatu omong kosong belaka, yang pada akhirnya nilai-nilai karakter yang diajarkan tersebut hanya akan berhenti pada pengetahuan tannpa makna. Selanjutnya dengan metode kegiatan rutinitas yaitu kegiatan yang dilakukan peserta didik secara terus menerus, contohnya: meletakkan sepatu dan sandal pada tempatnya, meletakkan barang yang dipinjam atau diambil pada tempatnya, membudidaya antri, membuang sampah pada tempatnya dan tidak makan dan minum sambil berdiri/berjalan. Kegiatan penting dilakukan guna memberikan pengalaman langsun serta pemahaman dan penghayatan nyata atas prinsip-prinsip karakter yang ditanamkan guru kepada peserta didik

2) Agar proses pendidikan karakter disekolah dapat berjalan secara optimal dan efektif maka pihak sekolah harus membangun komunikasi dan kerjasama dengan orang tua murid seperti membuat MOU untuk mendukung kegiatan dan program yang berkenaan dengan pendidikan karakter yang telah dirumuskan atau direncanakan disekolah.

\section{Penutup}

Berdasarkan hasil penelitian danpembahasan, maka penelitian mengenai pelaksanaan pendidikan karakter di Sekolah Alam Muara Bungo (SAMO) dapat disimpulkan bahwa pendidikansebagai berikut:

1. Penerapan Metode Belajar Bersama Alam (BBA) yang dapat membangun karakter anak pada Sekolah Alam Muara Bungo (SAMO) sudah berlangsung sejak sekolah berdiri pertama kali, hal ini dapat dilihat dari visi misi dan pilarpilar kurikulum sekolah alam yang megangkat tema-tema karakter. pembinaan akhlak, pengembangan logika, leadership, pengembangan kewirausahaan Nilai-nilai karakter yang terbentuk melalui metode BBA : beriman, peduli alam/ lingkungan, toleransi, disiplin, mandiri, berani, tanggung jawab, hidup hemat, rajin, Leadership. 
2. Terdapat beberapa kendala dalam pembinaan karakter anak di Sekolah Alam Muara Bungo (SAMO) yaitu Pertama: Masih adanya guru/anak yang belum disiplin dalam mengikuti aturan Pada sekolah alam muara bungo berlaku 5 pembiasaan yang menjadi orientasi pembinaan karakter yaitu (1) meletakkan sepatu dan sandal pada tempatnya, (2) meletakkan barang yang dipinjam atau diambil pada tempatnya, (3) membudidaya antri, (4) membuang sampah pada tempatnya dan (5) tidak makan dan minum sambil berdiri/berjalan. Kedua: Keterbatasan komunikasi yang dipengaruhi oleh jarak dan waktu antara guru dengan orang tua menjadikan program pembelajaran bagi anak tidak selalu dapat terwujud secara efektif.

3. Upaya guru mengatasi kendala dalam pembentukan karakter anak melalui penerapan Metode Belajar Bersama Alam (BBA) di Sekolah Alam Muara Bungo (SAMO): Pertama: menerapkan metode keteladanan Solusi yang dalam kegiatan sehari-hari kepala sekolah, guru, dan staf admnistrasi dapat menjadi teladan dan model yang baik bagi anak-anak disekolah selanjutnya Selanjutnya dengan metode kegiatan rutinitas yaitu kegiatan yang dilakukan peserta didik secara terus menerus. Kedua: Agar proses pendidikan karakter disekolah dapat berjalan secara optimal dan efektif maka pihak sekolah harus membangun komunikasi dan kerjasama dengan orang tua murid.

\section{Daftar Pustaka}

Anonimus. Sekolah Alam. Diakses dari https://id.m.wikipedia.org/wiki/sekolah_alam pada 8 Agustu 2019 pukul 4.44 WIB

Bambang, Q Anees dkk. 2008. Pendidikan Karakter Berbasisal-Quran, Bandung: Simbiosa Rekatama Media.

Julius. Dr. Gloria. 2016. Survey says: Developing good character in children starts early. Retrieved from Primrose School. Diakses dari https://www.primroseschools.com/blog/survey-says-building-good-characterin-children-starts-early/

Lickona, T. 2014. Pendidikan Karakter: Panduan Lengkap Mendidik Siswa Menjadi Pintar dan Baik. (Edisi terjemahan). Bandung: Nusa Media.

Lubis, Syahron. 2011. Metodologi Penelitian Pendidikan. Padang: Sukabina Press. Lufri. 2007. Kiat Memahami dan Melakukan Penelitian. Padang: UNP Press Riadi, Doni. “Belajar Bersama Alam”. Diakses dari doniriadi.gurusiana.id pada 30 Juni 2019 pukul 23.33 WIB. 
Saptono. 2011. Dimensi-dimensi Pendidikan Karakter: Wawasan, Strategi, dan Langkah Praktis. Salatiga: Erlangga.

Sari, I.P., \& Syamsi, K. 2015. Pengembangan Buku Pelajaran Tematik-Integratif Berbasis Nilai Karakter Disiplin dan Tanggung Jawab di Sekolah Dasar. Jurnal Prima Edukasia, Vol. 3(1), hlm. 73-83.

Suwarna \& Suharti. 2014. Pendidikan Karakter Hormat dalam Buku Pelajaran Bahasa Jawa di Sekolah. Jurnal Pendidikan Karakter, Vol. 4(2), hlm. 137148.

Suhendi dan Septriana Murdiani. 2011. Belajar Bersama Alam dengan Kurikulum Muatan Lokal yang Hidup. Bogor: SoU Publisher 